\title{
International Monetary Reform and the "Crawling Peg"-Reply
}

\author{
by GEORGE W. McKENZIE
}

T

HE PURPOSE of my article, "International Monetary Reform and the "Crawling Peg," was to propose that a more flexible system of international exchange rates should be substituted for the current mechanism, in light of the periodic exchange crises that the world has experienced over the past few years. My analysis emphasized how international financial variables could affect domestic monetary conditions, since I felt that this was a subject that had been largely neglected in recent public discussions. ${ }^{1}$

Furth's Comment contends that: (I) the assumptions of my analysis regarding financial relationships are false; (2) the recent international financial crises are really not as serious as they are made out to be, and hence, (3) there is no need to modify the present international monetary system in the direction of the "crawling peg." The purpose of this Reply is to argue that Furth's reasoning is factually or logically incorrect, and, as a result, his conclusions about the undesirability of the "crawling peg" are invalid.

\section{Assumptions of the Analysis}

Furth fails to recognize that one of the reasons for making simplifying assumptions in economic analysis is to clarify in detail the relationships between a few

\footnotetext{
1For additional discussion of financial relationships, see: $R$. A. Mundell, "Capital Mobility and Stabilization Policy Under Fixed and Flexible Exchange Rates" Canadian Journal of Economics and Political Science, November 1963 J. Carter Murphy, "Moderated Exchange Rate Variability," National Banking Review, December 1965; Ronald McKinnon and Wallace Oates, "The Implication of Internationa Economic Integration for Monetary, Fiscal and Exchange Rate Policy, "Princeton Studies in International Finance November 16, 1966 and James C. Ingram, "A Proposa for Financial Integration in the Atlantic Community," Fac tors Affecting the United States Balance of Payments, Ioint Economic Committee, 87th Congress, 2nd Session (1962).
}

important variables. ${ }^{2}$ In this way, it is possible to shed some light on economic processes which otherwise are extremely complicated and difficult to understand.

For policy purposes, however, it is desirable that our analysis be as close an approximation to reality as is necessary to give accurate answers. I would argue that, in light of our current knowledge, the framework presented in my article does indeed represent a reasonable approximation of reality. To see this, let us examine the three points raised in the Comment.

\section{International Pontolio Invesiment}

The analysis of international portfolio flows is considerably more complicated than Furth suggests. There may indeed be sophisticated foreign security traders who will liquidate part of their holdings of foreign equities during a period when monetary actions are restrictive. But will these people bring their funds home or reinvest them in short-term foreign assets? If they reinvest them in short-term foreign assets, a deterioration in the portfolio account will merely be offset by an improvement in the shortterm capital account. And, of course, there will be long-term investors who will merely try to weather out any potential storm.

Evidence presented by Rhomberg suggests that during the period when Canada operated under a system of flexible exchange rates, both direct and portfolio investment moved in the same direction as short-term capital in response to changes in Canadian.

\footnotetext{
2For a more detailed discussion of some of the problems of economic analysis, see Emest Nagel, "Assumptions in Economic Theory," American Economic Review, May 1963.
} 
interest rates. ${ }^{3}$ That is, an increase in yields on Canadian investments tended to attract foreign funds, predominantly from the United States.

\section{Covered Interest Arbizage}

Although Furth correctly argues that the flow of money-market funds responds to "covered" rather than "uncovered" interest rate differentials, this modification does not alter the conclusions of my paper. ${ }^{4}$

For example, consider the following hypothetical situation: interest rates in both Germany and France are roughly the same and there are no expectations of any exchange rate adjustments. As a result, there should be no spread between current and forward exchange rates. If the three-month forward cost of francs to Germans was, say ,81 deutsche mark (DM), as compared to a spot rate of $.80 \mathrm{DM}$, covered interest rate arbitragers would be induced to purchase French short-term assets and to sell their receipts forward. In this manner, the arbitragers would earn not only interest but also the difference between the spot and forward exchange rates. In the process, the demand for spot francs would increase, bidding their price up, while the increased supply of forward francs would bid the latter's price down. Hence, the spread between the two rates would be eliminated.

Let us again assume an initial situation where interest rates are equal in the two countries and there is no spread between the spot and forward rates. Then let us suppose that the German Central Bank undertakes restrictive policies which raise yields on short-term assets. Interest rate arbitragers will then purchase these assets and at the same time sell their mark proceeds forward in order to cover their investment. As a result, the spot franc price of marks will increase, and the forward rate will fall until the spread just offsets the interest-rate differential.

Of course, under the rules of the International Monetary Fund, spot exchange rates cannot vary significantly from their predetermined par value. ${ }^{5}$ This is a major point which Furth neglects. French authorities would intervene in the spot market after selling part of their reserves of gold. As a result, cash

\footnotetext{
3Rudolf Thomberg, "A Model of the Canadian Economy Under Fixed and Fluctuating Exchange Rates," Journal of Poltical Economy, February 1964, p. 10.

4For a detailed discussion of covered interest arbitage, as well as the hedging and speculative operations discussed in my article, see: Alan R. Holmes and Francis H. Schott, The New York Foretgn Exchange Market, Federal Reserve Bank of New York, 1965.

5For a diseussion of this particalar point, see Holmes and Schot, p. 55 .
}

balances in Germany would increase, moderating the initial attempt at a restrictive monetary policy. The conclusions are the same as those of my original article. ${ }^{6}$

Hence, Furth is in error when he states that, "a rise in gross money-market rates is not much more likely to set in motion a large inflow of money-market funds than to set in motion an outflow or - most often - to leave the flow substantially unchanged." The fact that movements of interest and forward exchange rates tend to offset each other is because of sensitive capital flows. In addition, as I have just explained, Furth is incorrect in asserting that a country's net international liquidity position will be unaffected. He has neglected the impact of exchange rate stabilization policies necessitated by the rules of the International Monetary Fund.

\section{Exchange Risks}

I disagree with Furth's statement that exchange risks or the other impediments mentioned in my article have severely restricted the mobility of capital. During the 1960's, the development of European currency markets has brought the financial centers of the world closer together. ${ }^{7}$ As a result, European authorities have had to be concerned with the possibility of large flows into or out of a particular banking system and its consequent implications for national monetary policy. For example, a country undertaking a restrictive monetary action will find that higher yields on short-term assets have attracted funds from abroad, and that this will tend to offset any decline in commercial bank reserves brought about by the restrictive policies. For this reason, European countries have often imposed controls on international capital movements to increase the effectiveness of monetary policy. ${ }^{8}$

The importance of such relationships cannot be underestimated. Today, restrictive monetary actions

\footnotetext{
George W. Mckenzie, "International Monetary Reform and the "Crawling Peg," in the February 1969 issue of this Review, pp. 15-23.

7For a more detailed explanation of the "Euro-currency" and Eurodollar matkets, see Fred H. Klopstock, "Euro-Dollars in the Liquidity and Reserve Management of United States Banks," Review of the Federal Reserve Bank of New York, July 1968; John E. Leimone, "The Euro-Dollar Markets," Review of the Federal Reserve Bank of Atlanta, August 1968 and Alan R. Holmes and Fred H. Klopstock, "The Market for Dollar Deposits in Europe," Revietw of the Federal Reserve Bank of New York, November 1960.

sSee Rodney H. Mills, "The Regulation of Short-Term Capital Movements," Staff Economic Studies, Board of Governors of the Federal Reserve System, May 22, 1968. Also, MeKenzie, p. 18.
} 
in the United States have encouraged American banks to tap European markets for funds. This, in turn, has caused interest rates in Europe to rise and has contributed to a growing concern over a potential slowdown in growth and a rise in unemployment there later this year.

\section{Monetary Policy, Speculation and the "Crawling Peg"}

Furth argues that institution of greater exchange rate flexibility through a "crawling peg" system would actually make anti-inflationary monetary policy less effective than under the present system. In support of this conclusion, he claims that once the exchange rate moves in a particular direction, people will expect it to continue moving in that direction, and hence there will be destabilizing international capital flows. Neither theory nor empirical evidence supports this assertion. Sven Arndt recently concluded that under a flexible exchange rate system, "speculators' expectations will be a slowly changing variable which possesses considerable inertia, and that speculative sales and purchases will have a dampening effect on movements in the exchange rate."

Actually, a strong case can be made that speculation is more destabilizing under the present system than would be the case under a "crawling peg." Today, it is usually quite clear in which direction the exchange rate will be altered in response to a prolonged payments deficit or surplus. Under a crawling peg, however, the exchange rate can move in either direction. Hence, the risk in taking a speculative position is increased.

In addition, if people believe that the ultimate equilibrium exchange rate requires further adjustment, then the capital flows described by Furth will actually be facilitating the movement to a new equilibrium..$^{10}$ A country undertaking restrictive monetary actions will experience a capital intlow as yields rise. This leads to a "crawling" appreciation which in turn causes a decline in the production of exports and import-competing substitutes. The restrictive monetary action is effective. If people expect the appreciation to continue, there will be an additional

\footnotetext{
9Sven Arndt, "International Short-Term Capital Movements: A Distributed Lag Model of Speculation in Foreign EXchange," Econometrica, Jantiary 1968, p. 69 . Arnde's results are derived from Canadian data for the period when that country operated under a Hexible exchange rate system.

1"See McKenzie, p. 20 and Milton Friedman, "The Case for Flexible Exchange Rates," Essays in Positive Economics, (Chicago: University of Chicago Press, 1953).
}

capital inflow which causes the exchange rate to appreciate further. This reinforces rather than weakens the impact of the restrictive policy. The capital flows, which Furth claims would be "unwanted" are actually fulfilling an important economic function.

This sequence of events depends on two conditions, however. The first is that exports and importsubstitutes should be sufficiently sensitive to changes in relative prices. Recent empirical evidence suggests that this is the case, at least for industrialized nations. ${ }^{11}$ The second condition is that the degree of exchange rate variability possible under the "crawling peg" should be great enough to assure the effectiveness of monetary policy. As I pointed out in my article:

If the peg is allowed to "crawl" at a slow rate, monetary policy will be almost as ineffective as under a fixed exchange rate system. If, however, the range of potential variability is reasonably wide, then monetary policy can be expected to have an influence on domestic economic activity within a relatively short period..$^{12}$

Thus, Furth's claim that the effect of an exchange rate change on exports and imports will be small, because the annual rate of crawl wotld be limited to two percent can actually be interpreted as a case for greater variability, say four per cent. ${ }^{13}$

Furth claims that the greater variability would bring about a conflict between international and domestic objectives. This argument again hinges on the assumption that once an exchange rate movement occurs, people will speculate that it will continue to move in that direction. Such behavior could cause a divergence between spot and forward rates up to the limit of the crawl. However, as I have pointed out above, both theory and fact do not support the likelihood of this happening.

\footnotetext{
11For comments on these results, see Ernest H. Freeg, "Elasticity Optinism in International Trade," Kyklos, 1967 , pp. 460-69.

12McKenzie, pp. 21-22. Within the limits of exchange rate variation prescribed by the "erawling peg" system, the autonomous demand for and supply of foreign exchange will be equal, and there will be no deficit or surplus, conttary to Furth's argument. However, should it be necessary for countries to dispose of or accumulate international reserves to keep exchange rates within prescribed limits, then there would be deficits or surpluses as under the present system. The greater the variability allowed, however, the smaller these imbalances will be.

13 This was approximately the average annual rate of change in Canada's rate when it operated under a flexible system.
} 


\section{Avoidance of Exchange Crises}

Furth argues that "the revaluation of the German mark (and the Netherlands gallder) in 1961; the difficulties of sterling since 1964; the difficulties of the French franc since May 1968; and the difficulties of the U.S. dollar over virtually the entire period" (my italics) were not as important as the critics of the system believe. This is a classic understatement.

David Rowan argued convincingly that the British decision to maintain a disequilibrium parity entailed the cost of slower economic growth and periods of reduced economic activity. ${ }^{14}$ Certainly, the British or French citizen today must be unhappy at having to endure austerity measures, ostensibly for balance of payments reasons. In addition, the periodic uncertainty and speculation has frequently widened the spread between spot and forward exchange rates so as to make hedging extremely costly. If exchange rate adjustment is to come (Furth seems to believe that it may at times be desirable), then it seems much more efficient to spread the adjustment over a period of time so as to minimize the impact of the attendant costs. ${ }^{15}$

Finally, I cannot agree with Furth's statement that the "problem of the French franc has been obviously unconnected with the present payments system." Spectlation that inflation following large wage increases would place the franc in disequilibrium and hence necessitate a devaluation certainly is an eco nomic reason for a capital outflow. His argument that if a devaluation of the franc was warranted, it should have been immediate and not a chronic downward "crawling" of the franc again neglects the costs of a large adjustment concentrated within a relatively short period of time. It is a moot question, of course, whether speculators could have anticipated Frances political difficulties and hence spread the exchange rate adjustment over a longer period of time.

\section{Implications of the "Crawling Peg" for the United States}

Furth states, without any supporting analysis, that the role of the U.S. dollar in the international economy would be seriously undermined under a "crawling peg" exchange rate system. This conclusion is doubtful. In fact, institution of the "crawling peg" system may very well lend greater stability, not only to the U.S. dollar but to all currencies as well.

\footnotetext{
14David C. Rowan, "Towards a Rational Exchange Policy: Some Reflections on the British Experience," in the April 1969 issue of this Review.

15 McKenzie, pp. 16-17.
}

It is important that we take a very close look at how greater exchange rate flexibility would affect us. First, we are the world's dominant importer and exporter. Second, we are a major international financial center, providing short-term assets and long-term loans to the rest of the world. Third, foreign govern. ments hold significant portions of their international liquidity positions in terms of dollars.

\section{The Impact on Trade in Goods and Services}

By definition, the "crawling peg" means greater variability in the prices paid for imports and those received for exports. On the supply side, this will affect the profitability of those sectors producing exports and import-substitutes as well as the profitability of marketing imported goods. On the demand side, consumers will adjust their expenditures in response to the relative prices changes in order to get the most for their dollar.

For the United States, such adjustments will have a smaller impact than for many of our trading partners simply because international trade is not as great a proportion of our economic activity. The question then is: do the responses to exchange rate variations under the crawling peg involve a greater or a smaller cost than under the present system?

After the British devaluation, an American company that had not hedged its sterling assets or export receipts would have suffered a large capital loss within a short period of time. Under the "crawling peg," the exchange rate adjustment and the losses could have been spread out over a longer period of time. In addition, under such a system, U.S. exporters expecting foreign exchange receipts would not be lulled into a false sense of security, but would hedge as a matter of course.

Under any exchange rate system, it is important that the cost of hedging activities should be kept within reasonable bounds. Today, a U.S. exporter expecting receipts from a country which might devalue could find the cost of hedging as high as ten or twenty per cent on an annual basis. The alterna tive for the exporter is to take a chance that devaluation will not occur. But this leaves him open to potential losses possibly greater than the cost of hedging. Thus, under such conditions, the present system can only discourage international trade rather than encourage it as its proponents claim.

\section{The Impact on the Capital Account}

Since the return to currency convertibility in 1959 , international capital movements have become in- 
creasingly important items in the balance of payments accounts of all countries. Under the present system, during periods of uncertainty a widening spread between spot and forward rates is capable of generating large international capital flows. The implications of such movements are quite important for the U.S., given the key role it plays in the "Eurocurrency" markets.

Basically, a Eurodollar is created when an American or foreigner transfers a dollar deposit to an account in a foreign bank, where he receives a higher interest rate. The foreign bank will then lend the dollars, usually at an interest rate lower than a borrower could obtain in the United States. Thus, if foreigners lost confidence in dollars, large outflows of funds could reduce the base on which the Eurodollar market operates and undermine the whole process of international financial intermediation.

Under the "crawling peg" however, the spot and forward exchange rates would be kept within close proximity by natural market forces and, hence, large speculative flows would be discouraged. In addition, the greater variability of exchange rates over the short-run would increase the risk involved in currency speculation, although it would not eliminate flows of this nature.

The impact of greater exchange rate variability on U.S. long-term investment is difficult to evaluate. Currently, such investors are open to large potential capital losses if a country should devalue. The crawl ing peg system would spread such losses over time rather than concentrating them within a short period. And, of course, long-term investors would receive capital gains in countries whose currency was appreciating. At present, such uncertainties do not discourage long-term U.S. investment abroad. And during the period when Canada operated its flexible system, American investment in that country grew rapidly.

\section{The Impact on the International Liquadity Position of the Unifed States}

Under the "crawling peg" system, exchange rates would be allowed to vary within predetermined limits during any period of time. In order to assure that rate movements do not exceed the predetermined bounds, countries would be obliged to hold stocks of international reserves which they would use to intervene in exchange markets when necessary. Howm ever, because exchange rates vary over time, this means that the value of a country's reserves may also change.
Many countries hold a portion of their international reserves in the form of dollars, the United States holds gold and a small amount of foreign currencies. Under a crawling peg system, should foreign currencies depreciate in terms of the dollar, the value of the stock of reserves to foreigners would increase while the value of our foreign currency reserves would decline ${ }^{16}$ However, this need cause no difficulties. Foreigners would find that their stock of international liquidity is increasing just at a time when it is needed to stabilize the exchange rate within the limits prescribed for the crawling peg. Similarly, the United States finds the value of its foreign currency reserves declining at a time when they need them least. In addition, because part of the international adjustment takes the form of an exchange rather than entirely reserve movements, the demand for international liquidity should be significantly smaller than under the current system. The implications of these circumstances, however, depend heavily on how central banks determine their desired holdings of international reserves.

Since the supply of gold is limited and the demand for consumer and industrial uses is growing, adoption of the crawling peg would provide a desirable opportunity to abandon gold as a reserve asset. However, it would seem useful. to provide for some form of reserve assets to supplement the use of foreign exchange. Presumably, this could take the form of the proposed Special Drawing Rights (SDR's). However, because SDR's are a media of exchange between governments, there would exist no free market for them. Consequently, they would have to be pegged in terms of some currency, and most likely this would be the dollar. ${ }^{17}$

A major argument in my original article was that international reserve movements under the present system are likely to have an offsetting impact on domestic monetary policies. This is much more likely to be the case for European countries than the United States. In order to preserve the viability of the system under current conditions, European authorities have an incentive to hold dollars rather than to place additional pressure on our gold stock. As a result there

\footnotetext{
16This assumes that no artangements have been made to cover foreign exchange reserves. Today under swap arrangem ments, one country can borrow foreign exchange from another, thereby adding to its reserves, while being guaranteed that it can repay the loan at the original exchange rate. This would occur even though a revaluation might have occurred in the interim.

it This would involve an alteration in the present proposal, which links SDR's to gold.
} 
is little direct effect on our monetary base when we have an international payments imbalance. However, a foreign central bank by accepting dollars for its own currency, will increase the monetary base of its own country.

\section{Conclusions and a Suggestion}

The conclusions of my original article still stand. However, I do not want to imply that application of the "crawling peg" or any other form of exchange rate flexibility can be achieved easily. Certainly more discussion is warranted concerning the formula to be used. For example, should the peg be based on a moving average of past exchange rates? How wide should the band of variability around the "crawling peg" be? How long a moving average should be adopted? Would it be necessary to develop additional hedging facilities?

The answers to these and other questions lie in the views of the business and banking communities. However, they have been strangely silent. Before additional discussion can proceed, it is necessary to elicit the reactions of those who actually are involved in international transactions to learn how much exchange rate variability they would be willing to accept and how they would react to it. In other words, a dialogue needs to be established. 